The book consists of three parts. In the first of these, treating of deep-sea waves, the evidence of various writers as to the dimensions of storm-waves in different ocean basins is collated, and supplemented by the author's own observations. Accurate measurements are from the nature of the case very difficult, but it appears that there is a limit to the height (from crest to trough), which different observers concur in placing at about 40 feet, whilst the limit to the length is somewhere about 600 feet. The waves are longer and higher the longer the "fetch," i.e. the extent of water to windward, where the waves are generated. As to the mode in which waves grow under the influence of wind in a storm, we have at present little beyond general indications. Another subject here referred to is that of the much longer and lower waves

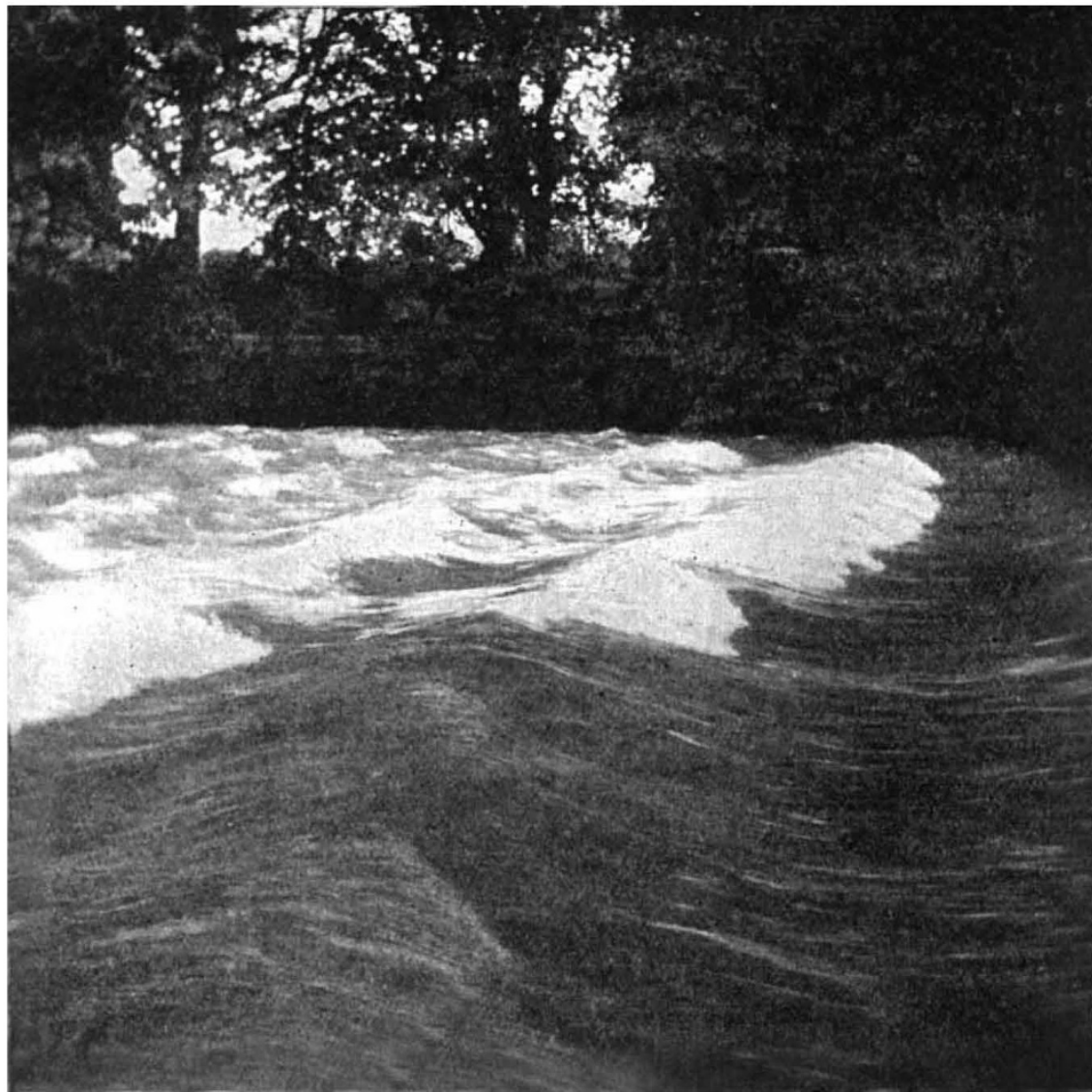

Fig. 2.-Stationary waves caused bv a weir on the River Aare, Switzerland. From "Waves of the Sea and other Water Waves.'

which constitute the "swell" of the ocean. To the eye this is often scarcely perceptible at sea, and the only method of accurate observations consists in timing the waves as they break on the shore, where they are exaggerated by the shoaling of the water. In this way some inferences can be made, as pointed out by Stokes, as to the distance of the seat of the original disturbance to which the swell is due.

The second part of the treatise deals with the action of sea-waves in transporting shingle, sand, and mud. This is of enormous practical importance, and can be dealt with to some extent experimentally. From a theoretical point of view it is very difficult, and we shall not attempt here to discuss the contribution which the author males to speculation on this subject.

The concluding section gives an interesting account, NO. 2 I 78 , VOL. 87$]$ with admirable illustrations, of the "bore" or abrupt tidal wave observed in the Severn and other rivers, and of the stationary waves in flowing water due to fixed obstacles. Finally, the remarkable configuration of "ship-waves," first elucidated by Lord Kelvin, is exhibited in some beautiful photographs. These show clearly the system of "transverse" waves, which were (we believe) unnoticed in the earliest tank experiments until their existence had been pointed out by theory.

FIVE-HUNDREDTH ANNIVERSARY OF THE UNIVERSITY OF ST. ANDREWS.

F ROM September I2-I5 next, inclusive, this celebration will be held in the ancient ecclesiastical capital of Scotland, with all the ceremony it is possible to have in the circumstances. Though the university was not founded until I4rr, yet St. Andrews for centuries previously had various teaching institutions in connection with the learned religious bodies in the monasteries of the Culdees and other sects concentrated in the ancient city, the preceptors of which had been trained in the English or Continental universities, especially those of France and Italy. Steps, indeed, had been taken before this period to further the interests of the Scottish students by the founding of the Scotch College (Balliol) at Oxford by Lady Devorguill, the wife of John Baliol; whilst the good Bishop of Moray had instituted in 1326 the Scotch College in Paris. No university, however, existed in Scotland, so that her students had to study for degrees elsewhere, and in the unsettled state of the times had not infrequently to encounter difficulties and hardshipseven to the occasional capture by their then hostile neighbours, the Englishon their way to other countries. Such was the condition of things when Henry Wardlaw was appointed to the bishopric of St. Andrews, and as he was a man distinguished for his wide culture, munificence, and great influence, it was not long before he found an opportunity. Eight years after his appointment to St. Andrews, viz., in I4II, the thoughts which doubtless had been revolving in his mind for a long time took shape and were put in action. A Studium Generale was at once commenced with the aid of a staff of able teachers in the faculties of law, divinity, and arts. He drew up a foundation-charter of the university, and forwarded it by envoys to the Pope (Benedict XIII.), who endowed it by means of papal bulls with all the powers of a university in $14 \times 3$ - to teach science, philosophy, and medicine, and this was subsequently confirmed by King James, who was throughout a staunch bene- 
factor to the young institution. Thus the Scottish youth were no longer compelled to seek higher instruction out of their own country.

At the celebration in September will assemble noblemen, one of whom, the Marquis of Ailsa, is the lineal descendant of Bishop Kennedy (grandson of Robert III.), the founder of St. Salvator's College, whose elaborately carved tomb is one of the sights of the college chapel; delegates from the universities of Britain, and all her Colonies and Dependencies; from America, Austria-Hungary, Belgium, Denmark, France, Germany, Greece, Holland, Italy, Japan, Norway, Portugal, Russia, Finland, Sweden, Switzerland, Spain, and Turkey. Besides others distinguished in science and literature, representatives of the various learned societies in Great Britain and her Colonies, of almost all the foreign countries mentioned, official persons connected with all the churches in Britain, officials of the College of Justice, naval and military authorities, parliamentary leaders and members, sheriffs and heads of various departments, will grace the ceremony, together with former teachers, graduates, and students of the university, and the present staff both of St. Andrews and Dundee.

The programme of the proceedings, as at present arranged, will comprise a reception by the Chancellor of the University, Lord Balfour of Burleigh, in the large temporary hall, St. Andrews, a students' torchlight procession, and a students' symposium on the evening of Tuesday, September 12. On Wednesday, September 13, a procession will be formed in the college quadrangle, and will proceed to the Church of the Holy Trinity, where a religious service will be held. Then, after an interval, the presentation of addresses will be made in the temporary hall, and thereafter an address will be given by the Chancellor. In the evening historical tableaux in the Great Hall, an illumination of the city, and a procession will take place. Lastly, a second students' symposium will conclude the proceedings of the day. On Thursday, September I4, a graduation ceremonial will be held in the Temporary Hall, at which a large number of distinguished honorary graduates in law (LL.D.) and divinity (D.D.) will be capped. Thereafter the rector, Lord Rosebery, who represents the students, and who will be escorted by a guard of honour formed of the Officers Training Corps of the university, will be installed, and will deliver his address. In the afternoon garden-parties will be held at Mount Melville, at St. Leonard's School for Girls, and probably also at the Gatty Marine Laboratory. In the evening a banquet will take place in the Bell Pettigrew Museum, which will likewise be declared open. Contemporaneous receptions by the ladies of the university will further occur, both in St. Andrews and in Dundee the same evening, so as to include all guests and hosts, and especially ladies and students. Friday, September I5, will be mainly devoted to Dundee, commencing with a reception and addresses at University College, followed by a reception by the Corporation of Dundee, and a luncheon in the Art Galleries of the Albert Institute. Thereafter, excursions to Glamis Castle, Rossie Priory, and a sail to Perth, as well as visits to places of interest in Dundee, will occupy the afternoon. The dav will be concluded by a graduates' and students' dinner in the Bell Pettigrew Museum, in St. Andrews, and a students' ball in the Temporary Hall.

The fine old ruins, so full of stirring historical associations, in St. Andrews, its old Tower of St. Regulus, usually called the Square Tower, one of the oldest buildings in the land, the home of Sir David Brewster, the most renowned principal of the university, the earliest Marine Laboratory in Britain, the fine Chemical Research Laboratory, the extensive stretch of sand-east and west-with the fringe of rocks, so full of interest to the geologist as well as to the zoologist, the zoological and botanical riches of the well-known bay, and the prominent part it has taken in initiating scientific fisheries' researchall combine to render the old cathedral city, where many Scotch parliaments were held, one of great interest. The unique silver maces, and the archery medals won by the young Scotch nobles who attended the university in the olden time, and many of whom afterwards became famous in the history of the country, are other features (not to allude to the splendid golf links) of interest to the distinguished visitors to the celebration of the 5ooth anniversary of the university in September.

W. C. M.

\section{NATIONAL ASSOCIATION FOR THE PREVENTION OF CONSUMPTION.}

\section{Conference on Tuberculosis.}

THE conference on tuberculosis, held on July I9-2I, organised in connection with the exhibition sent round the country by the National Association for the Prevention of Consumption, stationed at the Caxton Hall, Westminster, was as successful as those held during the past couple of years at Edinburgh, Cambridge, Oxford, and other centres throughout the country. Indeed, in certain respects the conference, recently brought to a conclusion, was more interesting and attracted greater attention than any one of its predecessors. The announced object of the conference was to discuss Mr. Lloyd George's Insurance Bill, or rather those sections and clauses of the Bill dealing with the prevention and treatment of tuberculosis; and at the opening meeting the members had the advantage of listening to an able address given by the President of the Local Government Board, who, as he himself put it, has, amongst his numerous and multifarious interests, specialised somewhat in tuberculosis and infant mortality.

Mr. Burns set himself to describe what has been done to bring down the mortality from tuberculosis during the last few years. As is usual with him, he illustrated his points by telling examples, of which two may be taken as likely to impress those interested in this subject even to the slightest extent. The first of these he drew from military life. A little more than thirty years ago the Guards were a body of eight thousand men--none finer or so fine in the world, maintained Mr. Burns-healthy, picked men, of fine physique, vet the death-rate from tuberculosis was a fraction above twenty. To-day what do we find? A little common-sense sanitation, better ventilation, and greater sobriety amongst the men together have brought down the death-rate from tuberculosis to $3 . \mathrm{r}$. As Surgeon-General Evatt insists: what has been done in the barracks it should be possible to do in civil life. Not so quickly, perhaps, but certainly in the long run.

Coming down to later times, Mr. Burns points cut that to-day in London only two persons succumb to tuberculosis where twenty years ago three lives constituted the toll to this disease. Again, for every two lives so lost in London, Berlin loses three and Paris five. This is a serious matter for our French friends, and "gives one furiously to think." How can this be accounted for? Certainly not by a single factor; but Mr. Burns makes a suggestion and gives certain figures that are well worthy of consideration. 